\title{
TELEOLOGIA AUTORSTWA
}

Prawo, prawość, prawda, prawy, prawowity, prawnik, sprawiedliwość. Nie zawsze uświadamiamy sobie, iż w języku polskim - jako historycznym odzwierciedleniu zbiorowej świadomości jego użytkowników - wszystkie te wyrazy mają wspólny źródłosłów. I właśnie ta okoliczność, w świetle której prawo spotyka się z prawda, prawością i sprawiedliwościa, ośmieliła mnie do wypowiedzenia kilku uwag i przemyśleń w gronie obecnych tutaj zacnych jurystów.

\section{SENS PRAWA AUTORSKIEGO}

Zacznijmy od podstawowego pytania: Po co stanowi się i po co istnieje prawo autorskie? Sam problem autorstwa nie jest niczym nowym w dziejach kultury śródziemnomorskiej, ale wydzielenie i skodyfikowanie tej sfery jurysdykcji dokonało się w kulturze ludzkiej ledwie paręset lat temu. Stosunkowo niedawno, jeśli zważyć, iż proceder kradzieży cudzej własności intelektualnej w swych spektakularnych niekiedy przejawach sięga zamierzchłej historii.

À propos tej ostatniej... Pytanie o głębszy sens prawa autorskiego, jakie przed chwila zadaliśmy, pada w czasach szczególnych, w których próbowano uśmiercić zarówno autora, jak i historię. Żyjemy w epoce przewartościowań, rewizji i negacji wszelkich imponderabiliów uważanych wcześniej za oczywiste i niepodważalne. W 1968 r. Roland Barthes w głośnym artykule Śmierć autora $^{1}$ zakwestionował i podał w wątpliwość dotychczasowy uzus stosowania tej podstawowej kategorii w odniesieniu do dzieła literackiego. W innych dziedzinach nauki także dał o sobie znać ów redukcjonistyczny kurs. Blisko ćwierćwiecze później Francis Fukuyama ogłosił na łamach amerykańskiego czasopisma „The National Interest” głośny esej historiozoficzny The End of History?2 ${ }^{2}$, by trzy lata później usunać znak zapytania i teraz już w formie oznajmiającej zradykalizować wymowę swej tezy w książce Koniec historii ${ }^{3}$.

\footnotetext{
${ }^{1}$ R. Barthes, La mort de l'auteur, „Manteia” nr 5, 1968, 4e trimestre. Przekład polski: Śmierć autora, przeł. M. P. Markowski, w: Teorie literackie XX wieku, red. nauk. A. Burzyńska, M. P. Markowski, Kraków 2006.

${ }^{2}$ F. Fukuyama, The End of History?, „National Interest” nr 16, Summer 1989.

${ }^{3}$ Idem, The End of History and the Last Man, London 1992, przekład polski: Koniec historii, przeł. T. Bieroń, M. Wichrowski, Poznań 1996.
} 
Życie dzisiejsze napisało jednak całkiem inny scenariusz, niż ten zawarty w nietrafnych przepowiedniach Barthes'a i Fukuyamy, w wyniku którego ani nie umarł autor, ani też nie skończyła się historia. I on w końcu ocalał, i ona trwa nadal. Idiom autorstwa - będący przez wieki charakterystycznym wyznacznikiem naszej tradycji kulturowej - na powrót staje się dzisiaj źródłem żywotności współczesnej sztuki i kultury Zachodu. I właśnie z tego względu, podobnie jak wszelkie inne rodzaje źródeł twórczej aktywności, powinien być za pomoca instrumentów prawnych pieczołowicie chroniony.

\section{AUTORSTWO JAKO WARTOŚ́́}

Gdyby poszukać w mitologii prawzoru sytuacji, jaka łączy dawcę daru wyrwanego bogom z ludzkością która ów bezcenny dar od niego otrzymuje, prefiguracją niezliczonej liczby autorów świata okaże się Prometeusz. Refleks prometejski obecny w akcie tworzenia zarówno artystycznego, jak i naukowego dotyczy zapewne wszelkich wiekopomnych darów, które otrzymał w swej historii rodzaj ludzki, ale uwagi moje ograniczam wyłącznie do autorstwa w sztuce. Choć oczywiście nic nie stoi na przeszkodzie, by rozszerzyć ich zakres również na zjawiska zachodzące w sferze twórczości naukowej.

I tu, i tam w grę wchodzi za każdym razem to samo - wspólny mianownik poznania i prawdy: w jednym przypadku artystycznej, w drugim naukowej. Poznania, za którym każdorazowo stoi rozpoznawalny podmiot sprawczy: kompozytor, poeta, dramaturg, powieściopisarz, eseista, malarz, rzeźbiarz, architekt, reżyser teatralny, filmowiec, artysta nowych mediów, wynalazca, odkrywca, uczony. Mit prometejski spotyka się w tym punkcie z innym - tym razem już nowożytnym - mitem człowieka owładniętego ideą tworzenia.

Mowa tu o micie faustycznym. W zbiorowej pamięci kultury nowożytnej to właśnie Faust jest prawzorem mitologii autora. Przekazując innym bezcenną wartość w postaci swego geniuszu, Faust staje się przez moment panem wszechrzeczy, jednak za chwilę nieopisanej radości tworzenia będzie musiał zapłacić najwyższą osobistą cenę. W szerszej perspektywie Prometeusza łączy z Faustem ów szczególny rachunek i niewyobrażalnie wysoki koszt kreacji, który płaci w swym życiu każdy prawdziwy twórca. Autorski akt stworzenia i osobistego ofiarowania, jakiego obaj się dopuszczaja, to czyn uzurpatorski i występny, będący aktem przekroczenia.

Twórczość stanowi dobro nieoczywiste. Tworzenie rzeczy, których nie ma, jest tak czy inaczej występkiem skierowanym przeciwko temu, co naturalne, istniejące, wiadome i powszechnie wyznawane. Sztuka i wiedza łączą się tutaj z dobrem społecznym i racją wyższego rzędu. W gruncie rzeczy podobnie bywa $\mathrm{z}$ tworzeniem wyposażonej w ludzki geniusz nadrzeczywistości filmów i cyfrowych światów wirtualnych. Zmieniają się technologie i instrumenty kreacji. Ona sama jednak zawiera w sobie ten sam co niegdyś magiczno-demiurgiczny refleks jednostkowej uzurpacji polegającej na wejściu w kompetencje boskie, a w każdym razie ze względu na swą moc sprawczą uważane za „nieludzkie”. 


\section{WSPÓLNY MIANOWNIK}

W dziedzinie mi najbliższej - to jest w sferze sztuki ruchomego obrazu zjawisko autorstwa jeszcze niedawno przeżywające głęboki kryzys wydaje się z wolna z niego wychodzić. Nowe media już nie szukają tożsamości w totalnej opozycji do sztuki filmowej. Znów jesteśmy gotowi odkrywać wielkość wspaniałych filmów, jakie nakręcili niegdyś: Friedrich Wilhelm Murnau, Abel Gance, Carl Theodor Dreyer, Luis Buñuel, Jean Renoir, Luchino Visconti, Roberto Rossellini, Ingmar Bergman, Federico Fellini, Alexandre Astruc, Albert Lamorisse, Jacques Tati, Robert Bresson, Andrzej Munk, Andrzej Wajda, Tony Richardson, Lindsay Anderson, François Truffaut, Miloš Forman, Pier Paolo Pasolini i in.

„Awangardziści raczej się mylili”“ - konstatował wkrótce po drugiej wojnie światowej Czesław Miłosz. Po nich nastała wielka formacja przywołanych tutaj autorów filmowych. Dzisiaj, po mniej więcej sześciu dekadach, jakie upłynęły od czasów świetności kina autorskiego na Starym Kontynencie, Europa, a wraz z nią również my, bardziej niż kiedykolwiek dotąd uświadamia sobie znaczenie autorstwa i wagę problematyki ochrony dóbr autorskich w dalszym rozwoju kultury. W kreowaniu nimbu autora kultura europejska zaszła nieporównanie dalej niż amerykańska. Doszło nawet do brzemiennego w skutki transferu idei autorskiej na tamtejszy grunt (Andrew Sarris i in.).

Nas jednak interesuje nie sam kult, lecz realne społeczno-kulturowe podłoże autorstwa utworu artystycznego jako pewnej doniosłej wartości obecnej w kulturze nowożytnej i nowoczesnej. Dzięki istnieniu owego szczególnego podłoża na równi liczą się: Antonio Gaudi, Witkacy, Pablo Picasso, Marcel Duchamp, Igor Strawiński, Charlie Chaplin, Wsiewołod Meyerhold, James Joyce, Virginia Woolf, Franz Kafka, Siergiej Eisenstein, Akira Kurosawa, Samuel Beckett, Federico Fellini, Woody Allen i Jim Jarmusch. Wszystkich ich, a także wielu, wielu innych, przy wszystkich różnicach, łączy jedno, a mianowicie wspólny symboliczny mianownik bycia autorem.

\section{ETYMOLOGIA AUTORA}

Uosobieniem wspólnego, a nie rozłącznego myślenia o nauce i sztuce uczyniłem w tym studium dwóch słynnych polskich uczonych, znanych profesorów Uniwersytetu Jagiellońskiego: Kazimierza Władysława Kumanieckiego (1880-1941) oraz jego syna Kazimierza Feliksa Kumanieckiego (1905-1977). Pierwszy z nich był prawnikiem, profesorem prawa administracyjnego, ministrem wyznań religijnych i oświaty publicznej w rządzie Juliana Nowaka (1922). Drugi - wybitny filolog klasyczny zwany polskim Cyceronem pozosta-

\footnotetext{
${ }^{4}$ Cz. Miłosz, Traktat poetycki, cz. II: Stolica, w: idem, Wiersze wybrane, Warszawa 1980, s. 73.
} 
wił po sobie przebogatą spuściznę refleksji nad kulturą i myślą antyku ${ }^{5}$. Skorzystajmy dla naszych celów z jego głębokiej wiedzy.

Wywodzacy się z łaciny wyraz 'autor' (auctor, auctóris) oznacza poręczyciela, jak również personalne źródło czegoś. W tym znaczeniu autor jest twórca dzieła, jego inicjatorem i sprawcą. Warto przyjrzeć się bliżej etymologii słowa 'autor', w której prawo spotyka się z twórczością i sztuka. Wyrażenie auctore alqo - czytamy w Stowniku tacińsko-polskim Kazimierza Kumanieckiego ${ }^{6}$ - oznacza 'pod czyimś kierownictwem, za porada, za sprawa, za inicjatywa czyjass'. Dalej mamy tu: 'założyciela', 'twórcę' i 'wynalazcę'. W sensie prawnym i politycznym auctor legis oznacza 'wnioskodawcę', lecz także 'świadka' i 'poręczyciela' a) co do ważności, b) co do własności, c) co do zastępstwa. Stąd wywodzi się pokrewny wyraz auctoritas oznaczający: 'poręczenie', 'porękę', 'uwierzytelnienie', 'wiarygodność', 'ważność', a także 'prawna własność', 'prawo własności', 'posiadanie?'.

Z rozważań nad etymologią autora i autorstwa wynika jasno, iż sprawczy charakter autorstwa stanowi jego istotę - zarówno w sztuce, jak i obliczu prawa; pozbawiony tego aspektu wyraz autor traci sens.

\section{PO CO CHRONIĆ AUTORA?}

Mimo iż, sięgając do kulturowej pamięci fenomenu autorstwa, powołuję się na Prometeusza i Fausta, w kwestiach dotyczących prawa nie zamierzam $\mathrm{w}$ żadnej mierze mitologizować postaci autora jako artysty. Wprost przeciwnie, traktuję go w tych rozważaniach jak Everymana, jednego z nas: zwyczajnego obywatela współczesnego świata, który w swym życiu postanowił zajmować się sztuką i twórczością. W centrum mojej uwagi znajduje się jego dzieło w połączeniu z nim samym. „W naszej epoce - pisał Wystan Hugh Auden - artysta ciagle jeszcze jest osobiście odpowiedzialny za to, co robi”".

Wymykające się próbom precyzyjnego zdefiniowania, społeczna wartość i doniosłość autorstwa polegają na tym, że dzieła z niego zrodzone, choć należą do podmiotu twórczego zwanego autorem, wyrażają w taki czy inny sposób zbiorową świadomość: jej ukryte pragnienia, dążenia, lęki, fascynacje, szczytne myśli i niespełnione marzenia. Przegląda się w nich zarówno pamięć wydarzeń niezwykłych, jak i życie codzienne. $\mathrm{Z}$ tego względu podział na twórczość wysokiego lotu i twórczość popularna traci sens. Dla jej potencjalnego adresata ważne sa: zarówno Napój cienisty, Sanatorium pod Klepsydra, Ferdydurke, Traktat poetycki i Kartoteka, jak i Miłość ci wszystko wybaczy, Pamiętasz, była jesień, Okularnicy, Addio, pomidory i Autobiografia.

\footnotetext{
${ }^{5}$ Kazimierz Kumaniecki habilitował się na Uniwersytecie Jagiellońskim w 1930 r. na podstawie rozprawy De consiliis personarum apud Euripidem agentium (O radach bohaterów sztuk Eurypidesa). Praca ta ukazała się drukiem w Serii Archiwum Filologicznego UJ, Kraków 1930.

${ }^{6}$ K. Kumaniecki, Stownik tacińsko-polski, Warszawa 1983, s. 58, s.v.

${ }^{7}$ Ibidem, s. 59, s.v.

${ }^{8}$ W. H. Auden, Poeta i społeczeństwo, przeł. A. Bartling, „Twórczość” 1968, nr 8.
} 


\section{KRAJOBRAZY AUTORSTWA W POLSCE}

Nasz dzisiejszy krajobraz autorstwa nie jest, niestety, jednoznaczny w swym wyrazie. Z jednej strony, od dwu dekad obowiązuja u nas skodyfikowane zasady i przepisy jego funkcjonowania. Wyznaczając je, uczyniono bardzo wiele, aby zaprojektować i umocować ustanowieniem prawa racjonalne rozwiązania legislacyjne, czego wyrazem stał się uchwalony w $1994 \mathrm{r}$. kodeks prawa autorskiego. $Z$ drugiej - panuje dość powszechne przekonanie, że prawo autorskie napotyka na co dzień wiele przeszkód formalnoprawnych i nie posiada jak dotąd należnej mocy sprawczej, której należałoby się po nim spodziewać w momentach spornych i chwilach zagrożenia. Nasi twórcy jako autorzy czuja się osamotnieni, a w niektórych konkretnych sytuacjach wręcz lekceważeni przez instytucje i urzędy.

Nikt wprawdzie w Polsce nie mówi autorowi „jesteś nikim”, ale sprowadzając go do roli bezradnego petenta i kłopotliwego intruza - nolens volens daje mu się odczuć, że znaczy nieskończenie mało. Upomniawszy się w tym miejscu o przywrócenie rodzimym twórcom należnego im statusu, domagamy się czegoś więcej niż stosowania obowiązującego prawa. Chodzi o to, iż poniża się, lekceważy i unieważnia nie tylko ich samych, lecz również własne dziedzictwo i kulturę, której żywotnym matecznikiem jest wszelka twórczość pojmowana jako społeczna - nieustannie odradzająca się w odpowiednich warunkach - energia tworzenia.

Tymczasem w obrębie matecznika rodzimego autorstwa od lat trwa jakby nic nielegalny wyrąb. Wielu skłonnych jest sądzić, że chodzi jedynie o wyrąb lasu prywatnego - proceder o lokalnej, a więc małej szkodliwości społecznej. Nic błędniejszego. Interes prywatny twórcy splata się tutaj i głęboko przenika z interesem publicznym. Strata poniesiona przez pojedynczego autora jest stratą nas wszystkich, każdy bowiem zamach na prawo autorskie dotyczy w gruncie rzeczy naruszenia własności będącej dobrem społecznym wyższego rzędu. Las jest własnością prywatna, ale czyste powietrze z niego - wspólne.

Dawne i nowe zagrożenia prawa autorskiego i pogarszająca się sytuacja polskich twórców nakazują podjęcie niezwłocznych działań. Planuje się dokonanie nowelizacji w prawie autorskim. Rzecz w tym, aby zmiany, jakie pociagnie ona za soba, były fortunne, nie zaś niszczyły i tak już zdewastowany krajobraz ochrony intelektualnej w naszym kraju. Istnieje ściśle powiązany z tym problem skuteczności ochrony. Nie trzeba do tego powoływać żadnych nowych organizacji, a jedynie zadbać o właściwe umocowanie prawne istniejących. Praktyka zbiorowego zarządzania prawami autorskimi mająca w Polsce długa tradycję przez dziesiątki lat udowodniła swoją skuteczność i niezbędność.

\section{EKOLOGIA AUTORSTWA}

Mowa tu o dziedzinie nad wyraz żywej, zmiennej i nieprzewidywalnej. Każde oryginalne dzieło autorskie jest przecież unikatowym prototypem, czymś, czego przed aktem jego kreacji realnie nie było. W momencie, kiedy się ono pojawia i zostaje urzeczywistnione $\mathrm{w}$ danym tu i teraz, staje się wartością wyma- 
gająca ochrony. Dlaczego? Ponieważ jako wartość symboliczna pozostaje nad wyraz wrażliwe i nie obroni się samo. Dlatego właśnie potrzebne jest mądre i skuteczne prawo, zdolne ocalić i w razie potrzeby wyegzekwować osobistą i zarazem społeczna wartość, jaką reprezentuje autorstwo utworu artystycznego.

Twórczość filmowa i audiowizualna stanowi w tej materii przypadek szczególny. Nie tylko ona, lecz również wszelkie odmiany twórczości łączą się z sobą w o wiele bardziej rozległą domenę artystycznej aktywności człowieka. Na co dzień nie zastanawiamy się nad autorstwem jako wrażliwym ekosystemem. Tymczasem autorstwo stanowi taki właśnie symboliczny ekosystem. Pieczę nad nim powinno (a mówiąc wprost - musi) sprawować państwo. Pozostawiony samemu sobie autorski ekosystem staje się całkowicie bezbronny i łatwo padnie łupem cudzej chciwości.

Owszem, ochrona kosztuje. Bez porównania więcej kosztuje jednak społeczeństwo jej brak. Nie jest to tylko problem w skali jednego państwa. Od pewnego czasu dochodzą do nas niepokojące sygnały dążeń części administracji brukselskiej lansujaccej rzekoma konieczność ograniczenia „tyranii” autorów dzieł i organizacji zbiorowego zarządzania ich prawami. Podejście to należy potraktować jako przejaw wyjątkowej, niebywałej wręcz nieodpowiedzialności organów i osób z racji pełnionej funkcji powołanych do ochrony publicznego dobra, jakim są twórczość i autorstwo.

Sięgnijmy w tym miejscu po z pozoru odległy przykład. W sierpniu $1915 \mathrm{r}$. armia niemiecka po triumfie pod Tannenbergiem zajęła Puszczę Białowieską. Od przynajmniej XV w. obszar ten chroniła władza królewska, wyznaczając określone przywileje użytkowania i ramy jego eksploatacji. W ciagu trzech i pół roku administracja niemiecka, prowadząc na tych terenach barbarzyńską gospodarkę rabunkowa, doprowadziła do degradacji zasobów Białowieży na niewyobrażalną skalę. Szacuje się, iż wycięto w tym okresie jedną piątą wspaniałego drzewostanu, wytrzebiono też niemal całkowicie zwierzynę.

Stawiam tezę, iż równie łatwo ulega spustoszeniu i degradacji pozostawiony bez należnej ochrony prawnej ekosystem autorstwa. Dlatego właśnie powinniśmy niezwłocznie zadbać o nowoczesna - precyzyjnie przemyślana i dostosowaną do dzisiejszych wymogów technologicznych oraz kontekstów społeczno-kulturowych - jurysdykcję autorstwa umożliwiającą realną ochronę tej sfery życia społecznego.

\section{AUTORSTWO JAKO PRZEMYSE}

Spośród państw szczycących się swoją kinematografią Stany Zjednoczone niewątpliwie osiagnęły w dziedzinie ochrony własnej twórczości artystycznej najwięcej. Dochodzenie roszczeń w tym zakresie prowadzone jest przez USA w sposób bardzo skuteczny. Dotyczy to zwłaszcza roszczeń w kwestii naruszeń praw autorskich poza granicami kraju. Prekursorskie w wielu kwestiach konstytucyjne regulacje prawne, jakie zostały przez Amerykanów wprowadzone już w XIX w., zdumiewają dojrzałością postanowień i perspektywicznie zaprojektowanym horyzontem kluczowych rozwiązań. 
Podam tylko jeden wymowny przykład: cokolwiek i gdziekolwiek ukazało się drukiem na terytorium Stanów, od 1870 r. począwszy, z mocy prawa musiało trafić w egzemplarzu obowiązkowym do zbiorów Library of Congress. Biblioteka Kongresu jako narodowy depozytariusz z kolei była zobowiązana do przechowywania z najwyższa pieczołowitością wszelkich artefaktów należących do narodowego dziedzictwa USA ${ }^{9}$. Dalekosiężny efekt tych systemowych działań znamy. Dzięki mądrości i skuteczności ustanowionego wówczas prawa ocalały w archiwach Biblioteki Kongresu nie tylko bezcennej wartości rzadkie druki, lecz także unikatowa kolekcja najstarszych filmów amerykańskich utrwalonych jeszcze nie na celuloidzie, lecz na zwitkach światłoczułych taśm papierowych.

Nie zmierzam do transferu rozwiązań prawa amerykańskiego na Stary Kontynent. Nie uważam ich wcale za optymalne. Zasada generalna tych regulacji upodrzędnia „twórcę” (creator) względem producenta jako posiadacza praw do utworu (copyright owner). Należy pamiętać, że przepisy prawne, jakie obejmują twórczość filmową i audiowizualna, ex lege „autorem” utworu czynią producenta, który dane dzieło wyprodukował. Reżyser, scenarzysta czy aktor staje się „autorem” tylko wtedy, gdy uzyska tytuł prawny ustanawiający go producentem bądź współproducentem.

Interesuje mnie jednak w tym momencie co innego, mianowicie aspekt skuteczności obrony praw autorskich. W Stanach Zjednoczonych uczyniono wiele, by je właściwie zabezpieczyć. Sztuka i twórczość w kulturze nowoczesnej to przemysł, a utwór audiowizualny bywa szczególnego rodzaju produktem. Prymat w kwestii autorstwa należy do producenta pod warunkiem, że nabył prawa do utworu. Przede wszystkim liczy się jednak pragmatyka i skuteczność obowiązującej jurysdykcji. Pod tym względem nie tylko Polska, ale i Europa ma jeszcze wiele do zrobienia. Nikt na świecie nie może równać się obecnie z Amerykanami w zakresie skutecznej ochrony własności intelektualnej oraz dóbr kultury artystycznej. Także w dziedzinie ruchomych obrazów. Nic dziwnego, skoro od dziesiątków lat kinematografia uchodzi w ich świadomości za jeden z przemysłów narodowych.

W europejskiej kulturze prawnej sprawy dotyczace materii autorstwa utworu audiowizualnego wyglądają nieco inaczej. Mocna jest zwłaszcza pozycja reżysera, zwanego - dla podkreślenia jego sprawczej autorskiej funkcji - „głównym reżyserem”. Na kontynencie europejskim uczyniono w ostatnich dekadach dużo, by nadać twórcy dzieła audiowizualnego odpowiednio eksponowany status. Owo „dużo” to ciagle jednak za mało, by można było mówić o właściwej (resp. skutecznej) ochronie jego autorskiego statusu i rzeczywistej ochronie praw z niego wynikających.

$\mathrm{Na}$ to, by owo prawo się zmieniło w dobrym kierunku, potrzebna jest zmiana świadomości. Nie wolno w polityce kulturalnej pomijać autora, podobnie jak nie należy go instrumentalizować. Żaden autor - w tym również autor utworu audiowizualnego - nie powinien być środkiem do niczyjego celu. Z pozoru mowa tu tylko o pewnej nagannej praktyce, wobec której prawo rzekomo nie obowiązuje. Czyżby?

${ }^{9}$ Zob. C. M. Highsmith, T. Landphair, The Library of Congress. America's Memory, Golden, Colorado 1994. 


\section{PRAWO AUTORSKIE JAKO WYRAZ ŚWIADOMOŚCI KULTUROWEJ}

Prawo autorskie w tej czy innej swojej postaci stanowi wyraz określonej świadomości zbiorowej dotyczącej autorstwa. Tam, gdzie ono nie sięga, funkcjonuje bezprawie. Najgorzej, gdy jest to bezprawie sankcjonowane przez bezsilność prawa. Glosy i komentarze do wyroków, jakie zapadają w materii prawa autorskiego, roztrzasają kwestie sporne i budzące zasadnicze wątpliwości. Cała nasza publikacja czerpie swój głębszy sens i merytoryczne uzasadnienie z poczucia troski o skuteczność obowiązującego w Polsce od dwu dekad prawa autorskiego. Zastanawiamy się nad celowością każdego postanowienia, szukamy lepszych niż dotąd rozwiązań. Czujemy, że mogą być one doskonalsze i lepiej dostosowane do codziennych realiów okołoautorskiej praktyki.

Ochrona prawna autora $\mathrm{w}$ dzisiejszym świecie musi mieć charakter głęboko przemyślany i systemowo zorganizowany. Głosy niepokoju dochodzące ze środowisk prawniczych dowodza, że jest $\mathrm{w}$ tych sprawach jeszcze wiele do zrobienia. Dopóki owa ochrona twórczej aktywności nie dostrzeże w jej indywidualnych przejawach i inkarnacjach organicznej cząstki wyższego porządku, jaki stanowi rodzimy przemysł kultury, nie znajdziemy - stanowiąc i korygując obowiąujące prawo autorskie - właściwego klucza naszych zabiegów i starań. A kluczem tym jest mądry i skuteczny mecenat państwa, które chroni przed zdewastowaniem nie tylko swoje lasy, rzeki i rezerwaty narodowe, lecz także zasoby, rezerwuary i wytwórnie myśli artystycznej i naukowej będącej nieoszacowanym bogactwem każdego państwa.

prof. dr hab. Marek Hendrykowski

Uniwersytet im. Adama Mickiewicza w Poznaniu

marekhendrykowski@gmail.com

TELEOLOGY OF AUTHORSHIP

Summary

Authorship is not an unknown concept in the history of the Mediterranean culture. As a matter of fact the phenomenon of authorship has been present since the ancient times and is much older than its protection. An interdisciplinary dialogue about protection and codification of copyright law began some five hundred years ago and led to an effective sustainable development in the entire Mediterranean area, playing in modern times a role of the cultural heritage. What is authorship today? Is it still a valid category? Who owns the movie rights? The essay introduces discussions on issues that are bound to engage readers attention (e.g. author's definition, copyright owner, media production, art of moving image, team working, collective creation, attribution, etc.) and provide a stimulating new way into exploring key concepts of copyright law in film and new media. 